\title{
Rural Manpower Utilization in Mgnregs in Dindigul District of Tamil Nadu
}

\section{Gnana Soundhari $\mathbf{P}^{1 *}$ and Promod Kumar $\mathrm{OB}^{2}$}

${ }^{1}$ Government Arts College, Coimbatore, Affiliated to Bharathiar University, Coimbatore. Christ poo, India

${ }^{2} P G$ and Research Department of Economics, Government Arts College, Coimbatore, Affiliated to Bharathiar University, Coimbatore, Tamil Nadu, India

\begin{abstract}
Many policy makers have recommended various measures for the development of rural India, since independence. Their study reveals that major portion of unskilled labourers is located in rural India. Mahathma Gandhi national rural employment guarantee scheme (MGNREGS) in Tamilnadu ensures 100 percent unskilled manual works. Dindigul district is an economically developing district in tamilnadu state. Where MGNREGS is being implemented well and where there is a history of distress migration, agriculture have not productive and looking at yields. Relating to age wise registered and employed persons, number of women beneficiary worker with account, category wise house hold workers to whom job card issued and who are active, Employment generated during the financial year 2013-14.
\end{abstract}

\section{Keywords: MGNREGS; Job card; Man power}

\section{Introduction}

Many policy makers have recommended various measures for the development of rural India, since independence. Their study reveals that major portion of unskilled laborers is located in rural India. For the proper development and utilization of the man power in the rural area, they have suggested various measures and programs for the upliftment of poor in rural areas. One such program implemented and followed very successfully is the MGNREG act. Prof. Jean Druze who is well known as father of MGNREG scheme for the especially unskilled manual work force [1-3].

The Mahatma Gandhi National Rural Employment Guarantee Scheme (MGNREGS) was the first ever Act internationally that guarantees wages employment and minimum level of livelihood security to the people in rural areas. MGNREG Scheme guaranteeing hundred days of wages- employment in a financial year to a rural household whose adult members volunteers to do unskilled manual work. It is also seeks to create durable assets to augment land and water resources, improve rural connectivity and strengthening the livelihood resources base of the rural poor [4].

\section{Growth performance of MGNREGP in Tamil Nadu}

The MGNREGP was launched on 02.02.2006 and was initially implemented in six districts viz., Cuddalore, Dindigul, Nagapattinam, Sivagangai, Thiruvannamalai and Villupuram from 2.2.2006 onwards and in four more districts viz., Thanjavur, Thiruvarur, Thirunelveli and Karur from 1.4.2007 onwards. From 1.4.2008 onwards, the scheme was extended to the remaining 20 districts of the state which are: Ariyalur, Dharmapuri, Perambalur, Pudukottai, Ramanathapuram, Namakkal, Vellore, Thoothukudi, Virudunagar, Salem, Erode, Thiruchirapalli, Kancheepuram, Theni, Tiruvallur, Madurai, Nilgiris, Kanniyakumari, Coimbatore, Kirhnagiri, and Tiruppur. Including the total number of blocks are 385 number of panchayats is 12,524 and number of village is $79,336[5,6]$.

Mahathma Gandhi national rural employment guarantee scheme (MGNREGS) in Tamilnadu ensures 100 percent unskilled manual works. To improve the quality of assets create under MGNREGS and to enhance the livelihood opportunities of the rural masses, the state has institutionalized an approach of resource convergence by inter weaving MGNREGS with other public works programs. The manual work needs to create sustainable assets that promote to economic and infrastructure development of village. Upto 2010-11 the major works taken up were large water bodies and community assets. The state has successfully implemented MGNREGS in collaboration with Agriculture, fisheries, horticulture and Nirmal Bharat Abhiyan (NBA) etc., the MGNREP is given more priorities to employment opportunity of rural people in Tamilnadu. MGNREP provided household employment to $62,39,073$ people in Tamilnadu during the period of 2006-07 to 2013-14. The number of household hold employment has increased from 683481 in 2000-01 to 6239073 in 2013-14. Due to favor of government policies, the participation of person days of women also increased [7].

There are many studies available regarding MGNREGS prospects and problems only few have attempted to study the performance over a period, taxing more than one point of time for the study. The present study has made an attempt for understanding rural manpower utilization in MGNREGA in dindigul district, Tamilnadu.

\section{Worksite facility}

Provision to special work opportunities to persons with disabilities mandatory. Provision of special employment facilities to households where no one is able to take up ordinary employment opportunities, due to disability or related reasons and ear-making of 3 percent of MGNREGS funds for employment persons with disabilities [8].

If a laborer got injured by accident arising out of and in the course of his employment under the Rural Employment Guarantee Scheme, he or she will be entitled to such medical treatment as is admissible under the scheme free of charge accommodation, treatment, medicines and a daily allowance which should not be less than half the wage rate.

\section{Objectives}

- To assess rural manpower utilization under MGNREGA in dindigul district.

${ }^{*}$ Corresponding author: Gnana Soundhari, Research Scholar, Govt. Arts College, Coimbatore, Affiliated to Bharathiar University, Coimbatore, Christ poo, India, Tel: 0422 - 2215212; E-mail: researchmentor100@gmail.com

Received May 20, 2015; Accepted June 16, 2015; Published June 26, 2015

Citation: Gnana Soundhari P, Promod Kumar OB (2015) Rural Manpower Utilization in Mgnregs in Dindigul District of Tamil Nadu Int J Econ Manag Sci 4: 269. doi:10.4172/21626359.1000269

Copyright: ( 2015 Gnana Soundhari P, et al. This is an open-access article distributed under the terms of the Creative Commons Attribution License, which permits unrestricted use, distribution, and reproduction in any medium, provided the original author and source are credited. 
- To assess the overall impact of MGNREGA on rural livelihood in the study area.

- To assess the employment generated in study area.

\section{Methodology}

Dindigul district is an economically developing district in Tamilnadu state. Where MGNREGS is being implemented well and where there is a history of distress migration, agriculture have not productive and looking at yields. The study is mainly based on secondary information. The data Collected by the ministry of rural development and MGNREGS website were the data source for the present study. Simple form of table with the Percentage calculated and the same have been analyses. Relating to age wise registered and employed persons, number of women beneficiary worker with account, category wise house hold workers to whom job card issued and who are active, Employment generated during the financial year 2013-14 [9].

\section{Employment Generated under MGNREGS}

Main aim of MGNREGS is to create employment opportunities for rural unemployed peoples in the gross root level. There for it is important to see how employment generated under MGNREGS in the Dindigul district. Therefore it is study is important to see how employment generated under MGNREGS in the study area. An outlay is made to analysis MGNREGs in the study are Dindigul district details of which furnished in tables.

Table 1 reveals that out of total population in the district registered under MGNREGS were about 1923014 in the year 2013-14. Among them 40870 persons registered are from 18-30 age group, while 133761 are from 31-40 age group, 140161 from 41-50 age group, 95252 from 51-60 age group and 53244 from 61-80 age group. Only 658 percent are belongs to above 80 age group. Natham block has highest registered persons among all block in the age group of 18-30, Reddiarchatram block has highest in the age groups of 31-40 and above 80. Thoppampatti block has highest in the age groups of 41-50, 51-60, and 61-80. Kodaikanal block has less number of registered persons among all block among all age group in Dindigul district.

Table 2 reveals that out of total people registered about 220948 people are employed in the year 2013-14. In that 16929 (7.66 percent) persons are employed which come under 18-30 age group, 62667 (28.36 percent) from 31-40 age group, 66903 (30.27\%) from 41-50 age group, 48069 (21.75\%) from 51-60 age group, 26193 (11.85\%) from 61-80 age group, and only $187(0.08 \%)$ who are above 80 age group.

\section{Bank Accounts}

In MGNREGS the government has made the role to disburse the wage amount through bank accounts directly to the beneficiaries account for the proper utilization of the fund. In this way MGNREGS workers are getting their wage amounts through bank and post office accounts. Below table shows the account opened and amount disbursed through bank accounts in the financial year 2013-14.

Table 3 reveals that out of total population 189971 individual accounts opened in bank and only 794 joint account opened in bank. for that, total 10983.72 lakhs amount of wage disbursed through bank account. In the same table it is seen that Thoppampatti block has majority of individual accounts about 19607 and Guziliamparai block majority of joint accounts about 188 in bank. Kodaikanal block have less number about 1678 individuals accounts and Shanarpatti block have very less number about 6 joint accounts. Regarding the amount disbursed through bank account for both individual and joint accounts. Thoppampatti block has 1245.531 lakhs amount disbursed which is highest amount among all blocks, and Kodaikanal block has very less amount disbursed about 69.942 lakhs in the year 2013-14.

Table 4 shows that category wise household workers to whom job card issued and who are active. Out of total population, total 329888 workers were issued job card and who are active. In that total workers about 93730 workers are belongs to SCs (scheduled caste) category, and 1024 workers are belong to STs (scheduled tribe) category whom job card issued and who are active participation of others category workers about 235134 to whom job card issued and who are active. Women workers are three-fourth of the total population about 242009 are active as for the MGNREGS norms [10].

Reddiarchatram block has more number of workers to whom job card issued and who are active among all categories among all the blocks. Kodaikanal block has less number of workers to whom job card issued and who are active among all categories among all blocks. Regarding women workers participation more 23890 found in Reddiarchatram block and less about 5607 found in Kodaikanal block (Table 5).

It is found that out of total population 8334 households to be employed in the financial year 2013-2014 and 17150 persons days Exceeding 100 days. Palani block has more number of household employed about 1240 and 2660 persons days Exceeding 100 days compared to other blocks. Kodaikanal block has very less number of household employed about 31 which Exceeding 100 days of person days about 72 .

It can be clearly from the Table 6 that total 248840 beneficiary workers found with account and in that 205705 beneficiary workers with account are women. The table also shows that Reddiarchatram block has more number of women workers about 19475 found with account and very less about 2820 women workers are found with account in kodaikanal block.

Table 7 reveals that out of total population 305101 households were issued job cards, in that 82817 number of household issued job card belongs to SCs category , 871 number of household issued job card belongs to STs category and 221413 number of household issued job card belongs to others category. Out of total household issued job card 186676 number of household provided employment, in that 50833 number of households provided employment belongs to SCs category, 335 number of households provided employment belongs to STs category and 135508 number of household provided employment are belongs to others. Out of total population number of job card issued 181668 numbers of women households are provided employment.

Table 8 reveals that out of total population 1,14,85,636 number of person days were generated. Out of total person day generated $31,95,776$ number of person days generated are from SC category, 17,861 number of person days generated are from ST category and $82,71,999$ number of person days generated are from other category. Out of total person days generated $1,01,27,116$ number of person days generated are women.

Out of total number of person days generated total number of 30128 families completed 100 days. Out of total number of families completed 100 days, 8701 number of families completed 100 days 


\begin{tabular}{|c|c|c|c|c|c|c|c|}
\hline \multirow[b]{2}{*}{ S.No. } & \multirow[b]{2}{*}{ Block } & \multicolumn{6}{|c|}{ Age wise registered persons } \\
\hline & & $\begin{array}{c}18-30 \\
\text { Registered person }\end{array}$ & $\begin{array}{c}31-40 \\
\text { Registered person }\end{array}$ & $\begin{array}{c}41-50 \\
\text { Registered person }\end{array}$ & $\begin{array}{c}51-60 \\
\text { Registered person }\end{array}$ & $\begin{array}{c}61-80 \\
\text { Registered person }\end{array}$ & $\begin{array}{c}\text { Above } 80 \\
\text { Registered person }\end{array}$ \\
\hline 1 & Athoor & 3486 & 10074 & 11150 & 8035 & 4944 & 28 \\
\hline 2 & Batlagundu & 3488 & 10188 & 11032 & 6951 & 4409 & 26 \\
\hline 3 & Dindigul & 2608 & 9823 & 9773 & 6335 & 3605 & 28 \\
\hline 4 & Guziliamparai & 2608 & 7225 & 7855 & 5922 & 3369 & 27 \\
\hline 5 & Kodaikanal & 1184 & 4801 & 4723 & 2942 & 1395 & 11 \\
\hline 6 & Natham & 5354 & 11500 & 11121 & 6440 & 1871 & 10 \\
\hline 7 & Nilakottai & 2812 & 9502 & 10022 & 6691 & 2921 & 6 \\
\hline 8 & Oddanchatram & 1896 & 7762 & 10514 & 8228 & 5196 & 42 \\
\hline 9 & Palani & 3170 & 11316 & 11856 & 8091 & 4324 & 24 \\
\hline 10 & Reddiarchatram & 4153 & 14145 & 13198 & 9553 & 6881 & 302 \\
\hline 11 & Shanarpatti & 3641 & 9428 & 9348 & 6728 & 3518 & 33 \\
\hline 12 & Thoppampatti & 3042 & 11344 & 13410 & 9491 & 6201 & 98 \\
\hline 13 & Vadamadurai & 1560 & 6567 & 6856 & 4004 & 1739 & 8 \\
\hline \multirow[t]{2}{*}{14} & Vedasandur & 2408 & 10086 & 9303 & 5841 & 2871 & 19 \\
\hline & Total & 40870 & 133761 & 140161 & 95252 & 53244 & 658 \\
\hline
\end{tabular}

Source: MGNREGS, website, ministry of rural development

Table 1: Age wise person registered in financial year 2013-14 in Dindigul district.

\begin{tabular}{|c|c|c|c|c|c|c|c|}
\hline \multirow{2}{*}{ S.No } & \multirow{2}{*}{ Block } & \multicolumn{6}{|c|}{ Age wise Employed Persons } \\
\hline & & 18-30 Reg.per & 31-40 Reg.per & 41-50 Reg.per & 51-60 Reg.per & 61-80 Reg.per & Above 80 Reg.per \\
\hline 1 & Athoor & 1610 & 4867 & 5571 & 4256 & 2531 & 11 \\
\hline 2 & Batlagundu & 1663 & 5576 & 5862 & 3915 & 2368 & 10 \\
\hline 3 & Dindigul & 730 & 2839 & 2729 & 2075 & 1194 & 8 \\
\hline 4 & Guziliamparai & 700 & 2996 & 3465 & 2744 & 1532 & 6 \\
\hline 5 & Kodaikanal & 235 & 980 & 671 & 462 & 226 & 1 \\
\hline 6 & Natham & 2329 & 5536 & 5139 & 3042 & 839 & 1 \\
\hline 7 & Nilakottai & 1210 & 4689 & 5235 & 3556 & 1451 & 0 \\
\hline 8 & Oddanchatram & 783 & 3760 & 5434 & 4286 & 2504 & 20 \\
\hline 9 & Palani & 1231 & 5365 & 5967 & 4307 & 2253 & 5 \\
\hline 10 & Reddiarchatram & 1587 & 6435 & 6224 & 4781 & 3214 & 61 \\
\hline 11 & Shanarpatti & 1906 & 5131 & 5099 & 3888 & 2076 & 15 \\
\hline 12 & Thoppampatti & 1115 & 6139 & 7380 & 5559 & 3571 & 40 \\
\hline 13 & Vadamadurai & 663 & 3251 & 3450 & 2060 & 856 & 4 \\
\hline \multirow[t]{2}{*}{14} & Vedasandur & 1167 & 5103 & 4677 & 3138 & 1578 & 5 \\
\hline & Total & 16929 & 62667 & 66903 & 48069 & 26193 & 187 \\
\hline
\end{tabular}

Source: MGNREGS, website, ministry of rural development

Table 2: Age wise person employed in financial year 2013-14 in Dindigul district.

belong to SC category, 58 number of families completed 100 days belong to ST category and 21369 number of families completed 100 days are others category.

\section{Conclusion}

In the summer season, like February, March, April and may are the months which are very horrible for the people of Dindugul district. In these days people under the study are facing worst situations like, high temperature, shortage of water, food problem, shelter problem inadequate tools in this condition they have to work in field or worksite. To escape from all this problems they think off migrate to cities in search of employment. So prevent migration and to provide better livelihood to the workers in dry land area like Dindugal district. It is required to allocation of more fund for MGNREGS work.

As strictly as possible policy makers formulate their planning programs to directly reach to the beneficiaries' corrupted hands finds many ways to misuitilize the allocated fund. But in MGNREGS the governments as well as policy maker are very conscious about making MGNREGS to reach the needy hands and their view become fruitful. Yet it is essential a systematic human resource policy is important to recruit and retain the appropriate teams at the national, state, district and sub district level. 
Citation: Gnana Soundhari P, Promod Kumar OB (2015) Rural Manpower Utilization in Mgnregs in Dindigul District of Tamil Nadu Int J Econ Manag Sci 4: 269. doi:10.4172/21626359.1000269

Page 4 of 5

\begin{tabular}{|c|c|c|c|c|}
\hline \multirow[t]{2}{*}{ S.NO. } & \multirow[t]{2}{*}{ Block } & \multicolumn{2}{|c|}{$\begin{array}{l}\text { No.of bank account } \\
\text { opened }\end{array}$} & \multirow{2}{*}{$\begin{array}{l}\text { Amount of wages } \\
\text { disbursed through } \\
\text { bank accounts 2013- } \\
2014 \text { (in lakhs) }\end{array}$} \\
\hline & & Individual & Joint & \\
\hline 1 & Athoor & 16615 & 49 & 908.29 \\
\hline 2 & Batlagundu & 17145 & 27 & 812.927 \\
\hline 3 & Dindigul & 8674 & 14 & 443.996 \\
\hline 4 & Guziliamparai & 8968 & 188 & 523.488 \\
\hline 5 & Kodaikanal & 1678 & 10 & 69.942 \\
\hline 6 & Natham & 15621 & 15 & 1007.844 \\
\hline 7 & Nilakottai & 15257 & 19 & 1060.279 \\
\hline 8 & Oddanchatram & 14333 & 63 & 842.562 \\
\hline 9 & Palani & 15167 & 102 & 983.057 \\
\hline 10 & Reddiarchatram & 16927 & 65 & 758.023 \\
\hline 11 & Shanarpatti & 17155 & 6 & 954.596 \\
\hline 12 & Thoppampatti & 19607 & 95 & 1245.531 \\
\hline 13 & Vadamadurai & 9575 & 31 & 608.127 \\
\hline \multirow[t]{2}{*}{14} & Vedasandur & 13249 & 110 & 765.058 \\
\hline & Total & 189971 & 794 & 10983.72 \\
\hline
\end{tabular}

Table 3: Account opened and amount disbursed through bank accounts in financial year 2013-14 in Dindigul district.

Source: MGNREGS, website, ministry of rural development.

\begin{tabular}{|l|c|c|c|c|c|}
\hline \multirow{2}{*}{ Block } & \multicolumn{4}{|c|}{ Workers to whom JC issued and who are active } \\
\cline { 2 - 6 } & $\begin{array}{c}\text { Number of } \\
\text { SCs }\end{array}$ & $\begin{array}{c}\text { Number } \\
\text { of } \\
\text { STs }\end{array}$ & $\begin{array}{c}\text { Number } \\
\text { of others }\end{array}$ & $\begin{array}{c}\text { Number of } \\
\text { total workers }\end{array}$ & $\begin{array}{c}\text { Number } \\
\text { of women }\end{array}$ \\
\hline Athoor & 7757 & 0 & 16520 & 24277 & 19522 \\
\hline Batlagundu & 9168 & 163 & 20123 & 29454 & 19077 \\
\hline Dindigul & 5781 & 3 & 9026 & 14810 & 12325 \\
\hline Guziliamparai & 6529 & 23 & 13451 & 20003 & 13654 \\
\hline Kodaikanal & 1897 & 444 & 7571 & 9912 & 5607 \\
\hline Natham & 3407 & 1 & 22633 & 26031 & 20778 \\
\hline Nilakottai & 7254 & 0 & 13494 & 20748 & 16714 \\
\hline Oddanchatram & 8147 & 70 & 17374 & 25591 & 19500 \\
\hline Palani & 13695 & 2 & 15438 & 29135 & 18572 \\
\hline Reddiarchatram & 5981 & 219 & 29425 & 35625 & 23890 \\
\hline Shanarpatti & 6049 & 2 & 17279 & 23330 & 19893 \\
\hline Thoppampatti & 10733 & 40 & 21743 & 32516 & 21707 \\
\hline Vadamadurai & 2877 & 53 & 12339 & 15269 & 12746 \\
\hline Vedasandur & 4455 & 4 & 18728 & 23187 & 18024 \\
\hline Total & 93730 & 1024 & 235134 & 329888 & 242009 \\
\hline
\end{tabular}

Table 4: Category wise house hold workers to whom job card issued and who are active in the financial year 2013- 2014 in Dindigul district.

Source: MGNREGS, website, ministry of rural development

\begin{tabular}{|r|c|c|c|}
\hline \multirow{2}{*}{ S.No } & \multirow{2}{*}{ Block } & \multicolumn{2}{|c|}{ Total attendance above 100 days } \\
\cline { 3 - 4 } & $\begin{array}{c}\text { House hold } \\
\text { employed }\end{array}$ & $\begin{array}{c}\text { Person days Exceding } \\
\text { 100days }\end{array}$ \\
\hline 1 & Athoor & 164 & 351 \\
\hline 2 & Batlagundu & 930 & 2229 \\
\hline 3 & Dindigul & 274 & 521 \\
\hline 4 & Guziliamparai & 380 & 665 \\
\hline 5 & Kodaikanal & 31 & 72 \\
\hline 6 & Natham & 443 & 904 \\
\hline 7 & Nilakottai & 563 & 1084 \\
\hline 8 & Oddanchatram & 736 & 1456 \\
\hline 9 & Palani & 1240 & 2660 \\
\hline 10 & Reddiarchatram & 495 & 1192 \\
\hline 11 & Shanarpatti & 716 & 1595 \\
\hline 12 & Thoppampatti & 885 & 1613 \\
\hline 13 & Vadamadurai & 497 & 757 \\
\hline 14 & Vedasandur & 980 & 2051 \\
\hline & Total & 8334 & 17150 \\
\hline
\end{tabular}

Table 5: Employment provided more than 100 days in financial year 2013-2014 in dindigul district.

Source: MGNREGS website, ministry of rural development.

\begin{tabular}{|c|c|c|c|}
\hline S.NO & Block & $\begin{array}{c}\text { No. of } \\
\text { beneficiary } \\
\text { worker with } \\
\text { account. }\end{array}$ & $\begin{array}{c}\text { Number of women } \\
\text { beneficiary worker with } \\
\text { account }\end{array}$ \\
\hline 1. & Athoor & 21282 & 17864 \\
\hline 2. & Baltagundu & 20418 & 15188 \\
\hline 3. & Dindigul & 12953 & 11440 \\
\hline 4. & Guziliamparai & 12681 & 10330 \\
\hline 5. & Kodaikanal & 3591 & 2820 \\
\hline 6. & Natham & 20454 & 18064 \\
\hline 7. & Nilakotai & 19785 & 16219 \\
\hline 8. & Oddanchatram & 18915 & 16005 \\
\hline 9. & Palani & 20025 & 15419 \\
\hline 10. & Reddiarehatram & 24341 & 19475 \\
\hline 11. & Shanarpatty & 21017 & 18519 \\
\hline 12. & Thoppmpatty & 23803 & 18884 \\
\hline 13. & Vadamadurai & 13310 & 11543 \\
\hline 14. & Vedasandur & 16265 & 13932 \\
\hline & Total & 248840 & 205705 \\
\hline
\end{tabular}

Table 6: Women worker bank account in financial year 2013-14 in dindigul district. Source: MGNREGS website, ministry of rural development. 
Citation: Gnana Soundhari P, Promod Kumar OB (2015) Rural Manpower Utilization in Mgnregs in Dindigul District of Tamil Nadu Int J Econ Manag Sci 4: 269. doi:10.4172/21626359.1000269

Page 5 of 5

\begin{tabular}{|c|c|c|c|c|c|c|c|c|c|c|}
\hline \multirow{2}{*}{ S.No } & \multirow{2}{*}{ Block } & \multicolumn{4}{|c|}{ HH issued jobcards } & \multicolumn{4}{|c|}{ No.of HH provided Employment } & \multirow{2}{*}{ Empolyment Provided No.of Women } \\
\hline & & SCs & STs & others & Total & SCs & STs & Others & Total & \\
\hline 1 & Athoor & 7199 & 2 & 17130 & 24331 & 5116 & 0 & 11212 & 16328 & 16108 \\
\hline 2 & Batlagundu & 6175 & 83 & 15304 & 21562 & 4390 & 76 & 10407 & 14873 & 14555 \\
\hline 3 & Dindigul & 8800 & 2 & 12405 & 21207 & 3542 & 2 & 5406 & 8950 & 8677 \\
\hline 4 & Guziliamparai & 4743 & 21 & 11560 & 16324 & 2681 & 20 & 6711 & 9412 & 9203 \\
\hline 5 & Kodaikanal & 1989 & 411 & 7541 & 9941 & 267 & 40 & 2038 & 2345 & 2211 \\
\hline 6 & Natham & 3394 & 0 & 23941 & 27335 & 1893 & 0 & 13784 & 15673 & 15194 \\
\hline 7 & Nilakotai & 8182 & 0 & 14810 & 22992 & 5187 & 0 & 9072 & 14259 & 13583 \\
\hline 8 & Oddanchatheram & 7294 & 65 & 16907 & 24266 & 4356 & 16 & 10588 & 14960 & 14262 \\
\hline 9 & Palani & 9836 & 13 & 13349 & 23198 & 6556 & 0 & 7893 & 14449 & 13798 \\
\hline 10 & Raddiarchatram & 4457 & 188 & 23815 & 28460 & 2902 & 122 & 15237 & 18261 & 17704 \\
\hline 11 & Shanarpatty & 6048 & 2 & 17964 & 24014 & 4125 & 2 & 12017 & 16144 & 16325 \\
\hline 12 & Thoppampatty & 7928 & 22 & 18079 & 26029 & 5749 & 21 & 12775 & 18545 & 17453 \\
\hline 13 & Vadamadurai & 2825 & 48 & 11307 & 14180 & 1772 & 33 & 7321 & 9126 & 9349 \\
\hline \multirow[t]{2}{*}{14} & Vedasandur & 3947 & 14 & 17301 & 21262 & 2297 & 3 & 11051 & 13351 & 13246 \\
\hline & Total & 82817 & 871 & 221413 & 305101 & 50833 & 335 & 135508 & 186676 & 181668 \\
\hline
\end{tabular}

Table 7: Employment generated during the Financial year 2013-14 in Dindigul District.

Source: MGNREGS website, ministry of rural development

\begin{tabular}{|c|c|c|c|c|c|c|c|c|c|c|}
\hline \multirow{2}{*}{ S. No } & \multirow{2}{*}{ Block } & \multicolumn{5}{|c|}{ No.ofpersondays generated } & \multicolumn{4}{|c|}{ Families completed 100 days } \\
\hline & & SCs & STs & other & Total & Women & SCs & STs & others & Total \\
\hline 1 & Athoor & 307997 & $\mathrm{O}$ & 641941 & 949938 & 853756 & 630 & 0 & 1824 & 2454 \\
\hline 2 & Battagundu & 264591 & 6135 & 578457 & 849183 & 694143 & 765 & 45 & 1419 & 2229 \\
\hline 3 & Dindugal & 194093 & 46 & 286801 & 480940 & 445380 & 472 & 0 & 480 & 952 \\
\hline 4 & Guziliamparai & 156683 & 1125 & 400821 & 558629 & 487621 & 318 & 0 & 1045 & 1363 \\
\hline 5 & Kodaikanal & 9617 & 1110 & 73460 & 84187 & 75559 & 6 & 0 & 74 & 80 \\
\hline 6 & Natham & 113298 & 0 & 863084 & 976382 & 910855 & 216 & 0 & 1613 & 1829 \\
\hline 7 & Nilakottai & 339499 & 0 & 596024 & 935523 & 834096 & 1116 & 0 & 1598 & 2714 \\
\hline 8 & Oddanchathram & 257021 & 1006 & 648927 & 906954 & 810952 & 612 & 1 & 1505 & 2118 \\
\hline 9 & Palani & 484962 & 0 & 528464 & 1013426 & 842819 & 1671 & 0 & 1557 & 3228 \\
\hline 10 & Raddiarchathram & 138318 & 4776 & 755789 & 898883 & 763791 & 163 & 3 & 1042 & 1208 \\
\hline 11 & Shanarpatty & 257565 & 179 & 745897 & 1003641 & 930208 & 495 & 1 & 1608 & 2104 \\
\hline 12 & Thoppampatty & 401736 & 1287 & 935544 & 1338567 & 1119979 & 1358 & 4 & 3803 & 5165 \\
\hline 13 & Vadamadurai & 121772 & 2065 & 502855 & 626692 & 584927 & 453 & 3 & 1958 & 2414 \\
\hline \multirow[t]{2}{*}{14} & Vedasandur & 148624 & 132 & 713935 & 862691 & 773030 & 426 & 1 & 1843 & 2270 \\
\hline & Total & 3195776 & 17861 & 8271999 & 11485636 & 10127116 & 8701 & 58 & 21369 & 30128 \\
\hline
\end{tabular}

Table 8: Employment generated during the financial year 2013-14 in Dindugul district.

Source:MGNREGS website, ministry of rural development

\section{References}

1. Vishwanathan PK, Amilmandal (2012) NREGS as Instrument of Gender main streaming an Exploratory Analysis. Man and Development 35: 17-36.

2. Venkata Naidu G (2012) NREGP -Social Exclusion and Inclusion A micro study on Emerging Trends of social in AP. Southern Economist 51: 19-21.

3. Thadathil MS, Mohandas V (2011) Impact of MGNREGS on Labour supply to Agriculture Sector of Wayanad district in Kerala. Agriculture Economics Research Review 24: 560.

4. Chathukulam, Jos Gireeson K (2007) Impact Assessment of NREGS in Kerala Evaluation of system and processes. Center for Rural Management, Kottayam, Kerala.

5. MGNREGA website, ministry of rural development

6. Revallion Martin (2015) Corruption in the MGNREGS Assessing an Index. Economic and political weekly. XLVII: 13-15.
7. Bharat S. Sontakki, Laxman M Ahire (2011) Rural Employment Guarantee Scheme: Boon or Bane to Indian agriculture? kurukshetra. 60: 39-44.

8. Shankar PS, Rao R Banerji N, Shah M (2006) Government Schedule of Rates: Working against rural Labour. Economic and political weekly 41: 1616-1619.

9. Shah D, Mohanty S (2010) Implementation of NREGA during Eleventh plan in Maharastra: Experiences, challenges and ways forward. Indian Journal of Agricultural Economics 65: 540-552.

10. Ghosh M (2010) Inclusive growth and rural poverty in India: Policy implication for eleventh plan.Indian journal of Agricultural Economics 65: 552-561. 